\title{
Evaluation of sex steroid hormones and reproductive irregularities in diethyl phthalate exposed premature mice: modulatory effect of raw honey against potential anomalies
}

\section{Chaman Ara}

University of the Punjab Quaid-i-Azam Campus: University of the Punjab

\section{Asmatullah}

University of the Punjab Quaid-i-Azam Campus: University of the Punjab

\section{Faiza Yaseen}

University of the Punjab Quaid-i-Azam Campus: University of the Punjab

Shaukat Ali ( $\square$ shaukatali134@yahoo.com )

Government College University Lahore https://orcid.org/0000-0003-2481-1978

Hafiz Abdullah Shakir

University of the Punjab Quaid-i-Azam Campus: University of the Punjab

Muhammad Khan

University of the Punjab Quaid-i-Azam Campus: University of the Punjab

Shagufta Andleeb

University of Education Lahore

\section{Nageena Ramzan}

University of the Punjab, Lahore

\section{Research Article}

Keywords: Phthalates, Honey, Antioxidant potential, TPC, Histopathology, Micrometry

Posted Date: May 28th, 2021

DOl: https://doi.org/10.21203/rs.3.rs-196112/v1

License: (c) (i) This work is licensed under a Creative Commons Attribution 4.0 International License. Read Full License 


\section{Abstract}

Phthalates, plasticizing chemicals are top-rated environmental contaminants. Diethyl phthalate (DEP), a chief member of this family was declared a potent endocrine-disruptor and carcinogen in animals and humans. The current study was designed to explore the probable reproductive damage induced by DEP and the therapeutic efficacy of raw honey in male albino mice. Four weeks old 50 male mice, were randomized equally in five groups, as control (C) received $0.1 \mathrm{ml}$ distilled water; vehicle control (VC) received $0.1 \mathrm{ml}$ corn oil; DEP ( $3 \mathrm{mg} / \mathrm{g} / \mathrm{BW})$ dissolved in corn oil; Honey control $(\mathrm{HC})$ administered 0.2 $\mathrm{mg} / \mathrm{g} /$ day) $\mathrm{P}+\mathrm{H}$ administered with DEP and honey ( $3 \mathrm{mg}$ and $0.2 \mathrm{mg} / \mathrm{g} / \mathrm{BW} /$ day respectively). Mice were treated through oral gavage for 54 days routinely, acclimatized for 6 days and dissected. In the first instance, the antioxidant potential and total phenolic contents of honey were analyzed through Ferric reducing antioxidant power assay and Folin-Ciocalteu assay to confirm the antioxidant capacity of honey. The morphological, morphometric, histological, micrometric, sperm count, hormonal analyses, and antioxidant capacity test in tissue homogenates were conducted by using tissues (testis, epididymis) and blood samples of mice. Mice exposed to DEP have a significant increase in body weight, LH level, seminiferous tubule lumen diameter and decrease in the gonado-somatic index, testosterone level, sperm count, and seminiferous tubule diameter. Additionally, histopathology of testes showed interstitial spaces dilations, exfoliations, Leydig cells atrophy, germ cell degenerations and spermatid retention in DEP exposed testes sections. However, concomitant use of honey and DEP had shown a significant improvement in histopathological lesions, steroid hormone levels, and healthy sperm count. By these results, it is concluded that honey possessed antioxidant potential that can efficiently protect DEPinduced anomalies in male mice.

\section{Introduction}

In the era of urbanization and industrialization, the general population is unavoidably exposed to various contaminants from diversified sources (Hernandez et al., 2019; Docea et al., 2018). It is highlighted by recent epidemiological and biomonitoring studies that exposure to these contaminants is associated with public health-hazardous that leads to nephrotoxicity, cardiotoxicity, hepatotoxicity, immunotoxicity, nephrotoxicity, as well as endocrine disruption (Andjelkovic et al., 2019; Buha et al., 2013; Docea et al., 2019; Tsatsakis et al., 2017). Some of the already proven and well-established chemicals involved in endocrine-disruption are, polybrominated diphenyl ethers, polychlorinated biphenyls, heavy metals, microplastics, pesticides, bisphenols as well as phthalates (Buha et al., 2018; Djordjevic et al., 2019; Gore et al., 2015). Recently, phthalates are considered top-listed classified endocrine disruptors that disrupt the hormonal balance on excessive exposure through diet, environment and daily household stuff (Tanner et al., 2020).

Phthalates are recognizable environmental pollutants that are frequently used as additives to enhance polymer versatility and malleability in the production of plastics. These are synthetic, colorless, odorless, and lipophilic compounds (Shaha and Pandit, 2020). In 1920, phthalates were first time used for commercial applications (Rahman et al., 2004). The six most familiar phthalates such as di (2-ethyl 
hexyl) phthalate, diethyl phthalate, dibutyl phthalate, dibenzyl phthalate, di-isopropanol phthalate were declared as environmental pollutants by the United States Environmental Protection Agency (Gani and Kazmi, 2020; Li et al., 2020).

Diethyl phthalate (DEP) is a widely used co-contaminant of microplastic and proved as an endocrine disruptor. It is structurally composed of alkyl chains with colorless, odorless and oily liquid nature soluble in the organic solvent (Zhou et al., 2020; Jeong et al. 2020). DEP is commonly used in pharmaceutics, medical bags, shampoo, perfumes, toys, and food packaging (Radke et al. 2020).

Although DEP has non-covalent bonding with plastic but makes it easy to leach in food products as well as the environment (NRC, 2009). When humans are exposed to DEP, it is metabolized into mono-ethyl phthalate (MEP) within 3 to $28 \mathrm{~h}$ (half-life) and eliminated from the body through urine (Radke et al., 2020). DEP compared to other phthalate detected more in the urine sample of the US population. Due to its ubiquity, its enormous and continuous exposure is associated with impaired fertility, shorter anogenital distance, increased oxidative damage to sperm cells and carcinogenesis (Hauser et al., 2007, Gopalakrishnan et al., 2020). Hence, animal studies are a prerequisite to understanding the potential link between diethyl phthalate exposure and adverse outcomes. These investigations may provide an understanding of the dose-related characteristics of phthalates. Therefore, it is inevitable to evaluate the noxious effects of diethyl phthalate on prepubertal mice's reproductive parameters.

On the other hand, honey is a natural sweetener and utilized enormously for health benefits (Selvaraju et al., 2019). It is made up as a result of regurgitation and evaporation of floral nectar by honeybees (Pipicelli et al., 2009). Honey consists of flavonoids, antioxidants, organic acid, minerals, protein, vitamins and carbohydrates such as fructose, sucrose, raffinose and glucose (Mosavat et al., 2019). These chemical constituents had made honey, a well-known antibacterial, antimicrobial and antifungal agent (Aswin and Neelusree, 2019). Ancient people used honey both for nutritional purposes and for its medicinal aims (Adebolu, 2005). Experimental studies support its usage due to its anti-inflammatory, antiviral, antibacterial, antioxidant and other bioactivities (Murosak et al., 2002). The therapeutic efficacy of honey is acknowledged in various major diseases, Diabetes, cancer, cardiovascular and degenerative diseases (Hossen et al, 2017). Its positive role as a nephroprotective agent in chemical-induced toxicity is also well-established (Ibrahim et al., 2016). Honey supplementation involved in-vitro maturation and improvement of sheep oocytes (Kaabi et al., 2020). Additionally, honey was also reported as an effective remedy to improve fertility status in males and females but results are still inconclusive (Meo et al., 2017). The present study aims to explore the therapeutic potential of honey against DEP-induced probable testicular lesions and reproductive disruptions in albino mice.

\section{Materials And Methods}

\section{Ethical statement}

All animal trials were executed according to local and worldwide procedures. The nearby way is the Wet op de dierproeven (article 9) of Dutch law (international) and an associated rule planned via the Bureau 
of Animal Research Licensing, Local University as detailed in our earlier papers (Ali et al. 2020; Hussain et al. 2020; Ali et al. 2020; Ara et al. 2020; Ali et al. 2020; Khan et al. 2019; Ali et al. 2019; Mumtaz et al. 2019; Mughal et al. 2019; Dar et al. 2019). The rearing and use of mice were carried out using NIH Publication "Guide for the Care and Use of Laboratory Animals" (NRC 2004) and with the approval vide No. D/681/UZ dated 04-04-2019 by the local bioethical committee of the University on animal experimentation.

\section{Chemicals}

Diethyl Phthalate 99.5\% purity, MW: 222.24 were purchased by Sigma Aldrich. Honey used in this research was multiflora honey collected in April from Apis mellifera colonies taken from Honeybee Research Farm, University of the Punjab, Lahore, Pakistan. Corn oil with $99.9 \%$ purity was purchased from the Akbari market, Lahore. Hormones Diagnostic Kits were BioVision Company, distributed by Lab Science, Pakistan. Ethanol, hematoxylin, eosin, hydrochloric acid, ferric chloride and ferrous sulphate were obtained from Merck \& Co., Inc. TPTZ (2,4,6-Tris(2-pyridyl)-s-triazine) was acquired from SigmaAldrich Company. All chemicals used in the present research were of analytical grade.

\section{Animals Rearing}

Swiss Webster strain of albino mice Mus musculus was used in the experiment. Mice were raised employing steel cages with well-managed conditions of 12 hours' light/dark cycle at $26 \pm 2{ }^{\circ} \mathrm{C}$ and $45-55 \%$ relative humidity in the animal house of the Institute of Zoology, University of the Punjab, Lahore, Pakistan. Mice were fed with commercially available feed (national feed No. 14 by National Feeds industries, Lahore, Pakistan) pellets and water ad libitum.

\section{Experimental Design}

Four-week-old 50 male mice with body weight (B.W.) $13 \pm 2 \mathrm{~g}$ were randomly classified into five groups $(\mathrm{n}=10)$. Group 1: control (C) provided $0.1 \mathrm{ml}$ distilled water; group 2: vehicle control (VC) administered 0.1 $\mathrm{ml}$ corn oil; group 3: DEP treated with $3 \mathrm{mg} / \mathrm{g} \mathrm{B.W}$. DEP, dissolved in corn oil in such a way that $0.1 \mathrm{ml}$ contained required concentrations of DEP; group 4: DEP (3 mg/g B.W) and honey $(0.2 \mathrm{mg} / \mathrm{g})$; Group 5 : honey control (HC) exposed to honey $(0.2 \mathrm{mg} / \mathrm{g} \mathrm{B.W})$. Treatments were given through oral gavage for 54 days daily, once a day. Before treatment, antioxidant potential and total phenolic content (TPC) were also assessed separately for raw honey used in this study.

\section{General observations}

Behavioral and other physical changes in mice of all groups were noted and recorded twice a day regularly. The body weight of each animal in each group was measured on weekly basis and dose concentrations were adjusted considering their weights accordingly.

\section{Samples recovery}


After 54 days, the animals were acclimatized for 6 days for self-restoration and were euthanized after isoflurane inhalation. Testes and epididymis were successfully recovered for morphometric, histopathologic, micrometric analyses, sperm count, and antioxidant capacity test (FRAP). The blood samples were collected by cardiac perfusion for hormonal assays under deep anesthesia.

\section{Morphometric Analysis}

Mice body weight and wet weight of the testes were measured with analytical balance (Ax120 SHIMADZU, JAPAN). Furthermore, the size (length/width) of testes was recorded using a digital Vernier caliper.

\section{Histopathology}

Testicular tissues were fixed in Bouin's fixative for $40 \mathrm{hrs}$ at room temperature $\left(33^{\circ} \mathrm{C}\right)$, dehydrated with graded ethanol, cleared with xylene and embedded in paraffin blocks. The thick sections $(5 \mu \mathrm{m})$ were prepared by rotary microtome and stained with eosin and hematoxylin following established protocols (Bancroft and Layton, 2013). The sections were observed and digital photographs were captured under a camera-fitted microscope to highlight histopathological defects and micrometric data.

\section{Micrometry}

For micrometric measurements, from photomicrographs taken at 40X, twenty nearly round randomly chosen seminiferous tubules were traced. Seminiferous tubule and lumen diameters were measured through bisecting lines drawn at the circumference of the tubule using ImageJ software at 400 magnifications (Montoto et al. 2012). The cross-sectional area of the seminiferous tubule (STA) was calculated following a geometric constant equation (Mustafa et al. 2019)

$$
\mathrm{STA}=\pi r^{2}
$$

Where $r$ is the tubule radius.

The area of the tubular lumen (LA) was calculated by the equation:

$$
\mathrm{LA}=\pi \mathrm{L} \mathrm{r}^{2}
$$

Where $L r$ is the luminal radius.

The epithelium area (EA) was obtained by subtracting LA from STA. Results were expressed as square millimeters $\left(\mathrm{mm}^{2}\right)$.

\section{Smear preparations for sperm count and morphology}

Testes with attached epididymis recovered in saline solution, give a midline incision, gently crushed on clean glass with a glass rod and curdy material used for the sperm count and sperm morphological 
analysis through the chamber counting method. The sperm with complete head and tail counted once in 4 big $1 \mathrm{~mm}^{2}$ quadrates under a light microscope (Kirkman-Brown et al., 2009).

\section{Hormonal Analysis}

Hormonal analysis for testosterone level and Luteinizing hormone were assessed in the mice blood samples by kits (BioVision). Hormones were assayed following kit instructions in triplicates.

\section{Antioxidant Capacity Test}

\section{Tissue homogenate preparation}

Testis tissues were preserved in $1.15 \%$ ice-cold $\mathrm{KCl}$ at $-80^{\circ} \mathrm{C}$ for few hours. Fresh testes were weighed and homogenates were prepared using a glass homogenizer with ice-cold $1.15 \% \mathrm{KCl}(10 \% \mathrm{w} / \mathrm{v})$ to record the antioxidant effect of honey within tissues. Then homogenates were centrifuged at $15000 \mathrm{rpm}$ for $10 \mathrm{~min}$ at $4^{0} \mathrm{C}$. The supernatants were collected for further processing (Katalinica et al., 2005).

\section{Ferric Reducing Antioxidant Power in mice tissues and honey}

The antioxidant power in tissues and honey was measured following the ferric reducing antioxidant power (FRAP) assay (Katalinica et al., 2005). The antioxidants present in the supernatant were evaluated as a reducer of $\mathrm{Fe}^{+3}$ to $\mathrm{Fe}^{+2}$, which is chelated by 2,4,6-Tris(2-pyridyl)-s-triazine (TPTZ) to form the complex and evaluated using the maximal absorption at $593 \mathrm{~nm}$. The results were presented in $\mu \mathrm{M}$ equivalent ascorbic acid/mg sample.

\section{Total Phenolic Content (TPC)}

Honey was assessed for the presence of phenolic contents following Valverde et al. (2015) protocol. Briefly, $1.0 \mathrm{~mL}$ of the diluted honey samples were transferred in separate tubes containing $5.0 \mathrm{~mL}$ of $1 / 10$ dilution of Folin-Ciocalteu's reagent in water. Then, $4 \mathrm{~mL}$ of a sodium carbonate solution $(7.5 \% \mathrm{w} / \mathrm{v})$ was added. The tubes were allowed to stand at room temperature for 60 min before absorbance at $765 \mathrm{~nm}$ was measured. The unit was expressed in a Gallic acid equivalent $\mathrm{g} / 100 \mathrm{~g}$ sample.

\section{Statistical analysis}

Statistical analysis was carried out using SPSS software (IBM, version 21.0). The data were expressed in terms of mean \pm SEM and mean differences between all experimental groups were measured by one-way ANOVA followed by Post hoc Tukey and Duncan's multiple range tests. All the tabulated data presented as mean \pm standard error of means and value $p<0.05$ was considered significant.

\section{Results}

\section{Biometric Parameters}


The morphological and morphometric analyses included mice body weight, gonado-somatic index (GSI), testes size (width and length) in all groups is presented in Figure 1 and Table 1. Animals in group C, VC, and $\mathrm{P}+\mathrm{H}$ showed normal morphology and morphometric results. However, the DEP group showed a significant $(P \leq 0.05)$ increase $(33.29 \pm 3.30 \mathrm{~g})$ and the $\mathrm{HC}$ group showed a remarkable decrease $(28.34 \pm 1.73 \mathrm{~g})$ in body weight gain against the control $(30.80 \pm 0.34 \mathrm{~g})$. Contrary to these findings, a decrease $(P \leq 0.05)$ in the testes weight and gonado-somatic index $(2.6 \pm 0.0033 \mathrm{~g})$ in the DEP group as compared to control $(0.8 \pm 0.0040 \mathrm{~g})$ was noted. On the other hand, $\mathrm{P}+\mathrm{H}$ (DEP co-administered with honey) showed significant improvement in the above-mentioned parameters.

\section{Micrometry and sperm count observations}

Micrometric observations in which post hoc analysis of means among groups showed significant variations $(p<0.05)$ in seminiferous tubule (ST) diameter and luminal diameter of the seminiferous tubule (Figure 2; Table 1). The group DEP showed significantly ( $p<0.01$ ) reduced ST diameter, $204.8 \pm 1.92 \mu \mathrm{m}$ and increased $(p<0.001)$ lumen diameter, $92.0 \pm 3.5 \mu \mathrm{m}$ as compared to control $(243.3 \pm 0.77$ and $67.1 \pm$ $1.3 \mu \mathrm{m})$. Contrary to this, the $\mathrm{P}+\mathrm{H}$ group showed less change $(\mathrm{p}<0.05)$ in diameter in comparison with the control. The cross-sectional area of seminiferous tubules (STA), decreases $\left(0.033 \pm 2.71 \mathrm{~mm}^{2}\right)$ remarkably $(p<0.05)$ in the DEP group contrary to the luminal area (LA), $0.0066 \pm 1.27 \mathrm{~mm}^{2}$ that increased significantly in the same group against controls $\left(0.046 \pm 1.40\right.$ and $0.0035 \pm 1.05 \mathrm{~mm}^{2}$, respectively). The results depicted a decline in mature sperms in the said group. STA and LA also showed variations in other groups as compared to control but the difference is less significant (Figure 2; Table 1). The above results are further cleared through sperm count, which decreased in a significant number $(p<0.001)$ in the DEP group (24.7 \pm 10.5 million $/ \mathrm{ml})$ as compared to the control (C) group $(41.8 \pm 2.11 \mathrm{million} / \mathrm{ml})$ (Table 2). The normal to abnormal sperm ratio is also comparable to the above results. A novelty found in the $\mathrm{HC}$ group (given honey solely), data about micrometric studies as well as sperm count showed more positive results even from the control group (Figure 2; Table 1-2).

\section{Hormonal Analysis}

The results of serum testosterone and luteinizing hormone quantification in all groups are presented in Figure 3. There was a statistically significant decrease $(p<0.001)$ in testosterone level $(0.10 \pm 2.05 \mathrm{ng} / \mathrm{ml})$, alternatively increased LH level $(2.02 \pm 4.15 \mathrm{mlU} / \mathrm{ml})$ was observed in the DEP group as compared to control, in which testosterone and LH levels were $0.24 \pm 3.22 \mathrm{ng} / \mathrm{ml}$ and $1.66 \pm 7.38 \mathrm{mlU} / \mathrm{ml}$, respectively. At the same time, the $\mathrm{P}+\mathrm{H}$ group showed comparable results with the $\mathrm{C}$ and $\mathrm{VC}$ groups with $0.23 \pm 1.26$ $\mathrm{ng} / \mathrm{ml}$, testosterone and $1.57 \pm 9.03 \mathrm{mlU} / \mathrm{ml}$, respectively. On the other hand, the serum testosterone levels in the $\mathrm{HC}$ group again showed a positive impact of honey on steroidogenesis.

\section{Antioxidant Capacity Test findings in Honey and testicular tissues}

There was a significant difference in reducing ability in terms of FRAP value among testicular tissues of various groups. FRAP value in DEP exposed testes tissues $(112.54 \pm 2.3 \mu \mathrm{M}$ ascorbic acid equi/ $\mathrm{kg}$ ) was significantly decreased $(p<0.001)$ as compared to $C(247.65 \pm 2.1)$ and VC $(250.67 \pm 1.1 \mu \mathrm{M}$ ascorbic acid 
equi/ kg). Moreover, FRAP indicated the successful enhancement of antioxidant capacity in testes tissues $(241.6 \pm 1.4)$ in the $\mathrm{P}+\mathrm{H}$ group compared to the DEP group (112.54 \pm 2.3$)$. On another side, testis of the animals who received honey solely (HC group) showed significantly higher FRAP value $(282.9 \pm 1.9 \mu \mathrm{M}$ ascorbic acid equi/ $\mathrm{kg}$ ) even than C group, which has a FRAP value of 247.65 2.1 (Table 3).

The findings of honey antioxidant capacity along with the total phenolic content were presented in Table 3. Results indicate a strong correlation $\left(R^{2}=0.9109\right)$ between TPC and antioxidant capacity (FRAP values) of honey (Figure 4).

\section{Histopathology}

Histopathological sections of testes from the control group (C) showed a regular pattern of seminiferous tubules surrounded by well-defined interstitial tissues. Primordial germ cells, spermatogonia are arranged in concentric layers on the intact basement membrane followed by layers of spermatocytes. The lumina of seminiferous tubules were filled with mature sperms (Figure 5 A1\&A2) Almost similar anatomical layouts were observed in $\mathrm{VC}$ and $\mathrm{HC}$ groups and $\mathrm{P}+\mathrm{H}$ group to a great extent (Figure $5 \mathrm{D}, \mathrm{E}$ and $\mathrm{C} 1$ \&C2 respectively). However, the DEP group showed severe kinds of pathological alterations including germ cell declination and degenerations, presence of residual bodies, Amyloids, degeneration of seminiferous tubules, exfoliations, Pyknotic nuclei, disrupted spermiation and Leydig cell autolysis. Even in the mitotic zone, spermatogonial cells were scattered and randomized. Wide luminal spaces were a clear indication for the declination of mature sperms (Figure 5 B1 and B2). However, the group $\mathrm{P}+\mathrm{H}$ showed the presence of healthy seminiferous tubules well occupied with germ and supporting cells (Sertoli cells) as compared to the DEP group (Figure 5 C1\&C2 and Table 4).

\section{Discussion}

Repeated exposure to DEP interferes with steroidogenesis as well as other reproductive parameters in developing mice. In this study, the mice's body weight gain was increased and they showed sluggish behavior after DEP treatment. Similarly, in another study, multiple phthalate types present in the urine samples resulted in an increased body mass index (BMI) of 5 to 12 years old children compared to unexposed individuals (Harley et al. 2017). Probably, the mechanism behind this was metabolites of DEP showed more affinity for PPARy receptors. It is strongly associated with commencing adipogenesis (Hurst and Waxman, 2003, Rodríguez-Carmona, 2019). Honey supplementation in the $\mathrm{P}+\mathrm{H}$ group successfully maintained the bodyweight like that of the control group and acted sometimes as a lipolytic compound. Another study on honey corroborated our findings, which stated that intake of $20 \%$ mono-floral honey reduced the body mass of rats (Nemoseck et al., 2011; Terzo et al.2020).

The testes morphometry of the DEP group in present data showed testicular hypoplasia resulted in a decrease in the testes weight, testes width and even gonado-somatic index. However, the length was similar to the control group. Several other researchers reported decreased gonadal size (Barakat et al., 2020). Where male mice were prenatally exposed with DEP mixture in $20 \mu \mathrm{g} / \mathrm{kg}$ and $500 \mathrm{mg} / \mathrm{kg}$ showed 
decreased gonadal weight in a dose-dependent way. In the $\mathrm{P}+\mathrm{H}$ group, testes showed improved morphological and morphometric parameters as compared to the DEP group.

Histological sections showed histopathological defects in DEP exposed testes like Leydig cell atrophy, degenerations, declination of germ cells, exfoliations, spacious lumen and disrupted spermiation. These findings are correlated with previous evidence in which DEP exposure causes degenerations of seminiferous tubules, thin basement membrane of testes and azoospermia (Mondal et al., 2019). In the $\mathrm{P}+\mathrm{H}$ group, the testes histology showed much improvement in interstitial tissues, healthy spermatozoa with more spermatogonia and Sertoli cells lining the basement membrane.

The micrometric observations revealed a significant reduction in seminiferous tubular diameter and a profound increase in the lumen diameter in the DEP group as compared to the control group. One obvious reason for the increase in luminal diameter is less production or degeneration of germ cells. Besides, honey supplementation increased seminiferous tubule diameter and decreased lumen diameter. Likewise, in another study, the utilization of honey enhanced the number of Leydig cells, seminiferous tubule diameter and decreased lumen size against cigarette smoke-induced toxicity (Mohamed et al., 2011). The protection against DEP instigated histopathological lesions seems that raw honey contains handsome amounts of flavonoids and other polyphenols which may function as antioxidants and the consumption of antioxidants along with the protection against various pathologies, has a lot of potential health benefits (Yeung, et al., 2019; Blassa et al., 2006).

There was a significant increase observed in luteinizing hormones and an alternatively decrease in testosterone levels in the DEP group. These results are justified by another study that an obvious decrease in gonadal size was correlated with decreased testosterone levels (Wang et al., 2004). The mechanistic approach of the present study is in line with other researchers (Ozcan-Sezer et al., 2019). The possible cause of impaired fertility in males was the increased number of adipose tissues and simultaneously P450 aromatase enzymes which convert the testosterone to estrogen hormone (OzcanSezer et al., 2019). Similar research reported where DEP and other phthalates exposure resulted in a significant decrease in testosterone level, mice body weight, and testes weight in human fetal testes (Sedha et al., 2021). Furthermore, the sperm count and morphology were also significantly affected in our observations, probably due to the hormonal imbalance by DEP. But another research contradicts aforementioned studies, it states that DEP exposure may induce androgen-independent male reproductive toxicity (James et al., 2020).

The sperm number and percentage of normal sperm also decreased in the DEP group, simultaneously abnormal sperm percentage significantly higher than the control group. In previously reported data, DEP exposure caused a reduction in sperm motility and sperm density while sperm count has not exhibited any change among treatment and control groups (Mondal et al., 2019). All these findings were a clear indication of diethyl phthalate caused a decrease or reduce fertility rate. Our data indicates in animals exposed to honey, testosterone level increased above average, while the LH level has decreased in the same mice. Various researches proved that honey maintained the level of testosterone (Banihani, 2019). 
Less adipose tissue and more Leydig cell stimulated the testosterone balance in the body of male mice. Thus, honey is also loaded with a chrysin molecule which acts as the inhibitor of the aromatase enzyme in adipose tissues. The inhibition of the aromatase enzyme resulted in decreased conversion of testosterone into estrogen, hence testosterone level maintained (Jeong et al., 1999). In contrast to our results, honey administration raised the LH level in the blood serum (Kolawole, 2015). Similar to our outcomes, honey supplemented to rats in diabetic conditions maintained the LH level in blood serum (Nasrolahi et al., 2013).

Our results clearly showed the direct and strong correlation between antioxidant capacity and total phenolic compounds. The increase in phenolic contents ultimately increased the antioxidant capacity. Another research reported that there was a positive correlation between antioxidant capacity and total phenolic contents of honey analyzed through FRAP and TPC assay, respectively. Honey was enriched with antioxidant compounds and stabilized ROS by enhancing the activity of catalase and superoxide dismutase enzymes (SOD) (Mohamed et al., 2011). Thus, treatment with honey has shown clear histopathologic, morphometric, steroidogenic and micrometric recoveries against DEP instigated reproductive deteriorations in mice.

\section{Conclusion}

The present research showed that total phenols present in honey act as free radical scavengers and significantly prevent diethyl phthalate-induced reproductive damages in male mice. Multiflora honey from Apis mellifera can efficiently protect testicular lesions and hormonal deviations during the biological development of mice. Our observations revealed the remedial efficacy of honey on the reducing ability of testes, hormone production, and reclamation of germ cells and micrometric dimensions of seminiferous tubules. Based on the current findings we suggest honey consumption revitalize spermatogenesis and steroidogenesis in mice exposed to environmental contaminants like DEP. Further studies are needed relating oxidative response and mechanism of action of honey against DEP in the mammalian model.

\section{Declarations}

\section{Acknowledgments:}

We are thankful to the officials of the University of the Punjab, Lahore Pakistan for providing research facilities.

\section{Consent to Participate:}

The rearing and use of mice was following NIH Publication "Guide for the Care and Use of Laboratory Animals" (NRC 2004) and with the approval by the local ethical committee of University of the Punjab, Lahore, Pakistan on animal experimentation (can provide a certificate on demand)

*Statement about this also added in manuscript. 


\section{Ethical statement:}

All animal trials were executed according to local and worldwide procedures. The nearby way is the Wet op de dierproeven (article 9) of Dutch law (international) and an associated rule planned via the Bureau of Animal Research Licensing, Local University as detailed in our earlier papers (Ali et al. 2020; Hussain et al. 2020; Ali et al. 2020; Ara et al. 2020; Ali et al. 2020; Khan et al. 2019; Ali et al. 2019; Mumtaz et al. 2019; Mughal et al. 2019; Dar et al. 2019). The rearing and use of mice were carried out using NIH Publication "Guide for the Care and Use of Laboratory Animals" (NRC 2004) and with the approval vide No. D/681/UZ dated 04-04-2019 by the local bioethical committee of the University on animal experimentation.

\section{Consent to Publish:}

"Not applicable"

\section{Authors Contributions:}

Conceptualization: Chaman Ara, Asmatullah: Data Curation: Chaman Ara, Asmatullah, Faiza Yaseen, Shaukat Ali, Nagina Ramzan, Hafiz Abdullah Shakir, Shagufta Andleeb, Muhammad Khan: Formal Analysis: Chaman Ara, Asmatullah, Faiza Yaseen, Shaukat Ali, Nagina Ramzan: Investigation: Chaman Ara, Asmatullah, Shaukat Ali, Hafiz Abdullah Shakir, Muhammad Khan: Methodology: Chaman Ara, Asmatullah, Faiza Yaseen, Shagufta Andleeb, Shaukat Ali, Nagina Ramzan, Hafiz Abdullah Shakir, Muhammad Khan: Histopathology: Faiza Yaseen, Nagina Ramzan, Muhammad Khan: Software: Shaukat Ali, Hafiz Abdullah Shakir: Supervision: Chaman Ara, Asmatullah: Writing Original draft: Faiza Yaseen, Nagina Ramzan, Hafiz Abdullah Shakir, Shaukat Ali, Muhammad Khan, Shagufta Andleeb: Review and Editing: Chaman Ara, Asmatullah, Shagufta Andleeb, Shaukat Ali, Hafiz Abdullah Shakir

Funding: There is no specific funding concerning this article, we are highly obliged to the Institute of Zoology, University of the Punjab, Lahore, Pakistan for providing us research facilities.

Competing Interests: Authors declared no kind of financial and authorship conflict.

Availability of data and materials: Most of the data generated during this study are included in this article. However, raw data sheets and histopathological Figures are available from the corresponding as well as co-authors upon reasonable request.

\section{References}

1. Adebolu TT (2005) Effect of natural honey on local isolates of diarrhea causing bacteria in Southwestern Nigeria. Afr J Biotechnol 4:1172-1174

2. Ali S, Awan Z, Mumtaz S, Shakir HA, Ahmad F, Tahir HM, Ulhaq M (2020) Cardiac toxicity of heavy metals (cadmium and mercury) and pharmacological intervention by vitamin $\mathrm{C}$ in rabbits. Environ Sci Pollut Res Int 27(23):29266-29279 
3. Ali S, Bashir S, Mumtaz S, Shakir HA, Ara C, Ahmad F, Tahir HM, Faheem M, Irfan M, Masih M, Ulhaq M, Andleeb A (2020) Evaluation of cadmium chloride-induced toxicity in chicks via hematological, biochemical parameters and cadmium level in tissues. Environ Sci Pollut. DOI:10.1007/s12011-02002453-9

4. Ali S, Ejaz M, Dar KK, Nasreen N, Ashraf N, Gillani SF, Shafi N, Safeer S, Khan MA, Andleeb S, Mughal TA (2020) Evaluation of chemopreventive and chemotherapeutic effect of Artemisia vulgaris against diethylnitrosamine induced hepatocellular carcinogenesis in Balb C mice. Braz J of Biol 80(3):489496

5. Ali S, Hussain S, Khan R, Mumtaz S, Ashraf N, Andleeb S, Shakir HA, Tahir HM, Khan MKA, Ulhaq M (2019) Renal toxicity of heavy metals (cadmium and mercury) and their amelioration with ascorbic acid in rabbits. Environ Sci Pollut Res Int 26(4):3909-3920

6. Andjelkovic M, Djordjevic AB, Antonijevic E, Antonijevic B, Stanic M, Kotur-Stevuljevic J, SpasojevicKalimanovska V, Jovanovic M, Boricic N, Wallace D et al (2019) Toxic E_ect of Acute Cadmium and Lead Exposure in Rat Blood, Liver, and Kidney. Int J Environ Res Public Heal 16:274

7. Yeung AWaiK, Tzvetkov,Osama NT, El-Tawil S, Bungǎu SG, Abdel-Daim MM, and Atanas G. Atanasov. (2019). Antioxidants: Scientific Literature Landscape Analysis. Oxidative Medicine and Cellular Longevity Volume 2019, Article ID 8278454, 11 pages https://doi.org/10.1155/2019/8278454

8. Ara C, Asmatullah, Butt N, Ali S, Batool F, Shakir HA, Arshad A (2020) Abnormal steroidogenesis, oxidative stress and reprotoxicity following prepubertal exposure to butyl paraben in mice and protective effect of Curcuma longa. Environ Sci Pollut DOI. 10.1007/s11356-020-10819-8

9. Aswin PS, Neelusree P (2019) To Study the Antimicrobial Properties of Honey on Common Microorganisms. Int J Curr Microbiol App Sci 8(9):114-121

10. Bancroft JD, Layton C. The Hematoxylin and eosin. In: Suvarna S. K, Layton C, Bancroft J. D, editors. Theory Practice of histological techniques. 7th ed. Ch. 10 and 11. Philadelphia: Churchill Livingstone of El Sevier; 2013. pp. 179-220

11. Banihani (2019) SA. Mechanisms of honey on testosterone levels, Heliyon. 2019. 5,(7):e02029

12. Barakat R, Seymore T, Lin PC, Park CJ, Ko CJ (2019 May) Prenatal exposure to an environmentally relevant phthalate mixture disrupts testicular steroidogenesis in adult male mice. Environmental research 1:172:194-201

13. Barakat R, Po-Ching Lin CJ, Park M, Zeineldin S, Zhou S, Rattan E, Brehm, Jodi A, Flaws, CheMyong J, Ko (2020) Germline-dependent transmission of male reproductive traits induced by an endocrine disruptor, di-2-ethylhexyl phthalate, in future generations. Sci Rep 10:5705

14. Beretta G, Granata P, Ferrero M, Orioli M, Facino RM (2005 Mar) Standardization of antioxidant properties of honey by a combination of spectrophotometric/fluorimetric assays and chemometrics. Anal Chim Acta 28(2):185-191 533(

15. Blassa M, Candracci M, Accorsi A, Piacentini MP, Albertini MC, Piatti E (2006) Raw millefiori honey is packed full of antioxidants. Food Chem 97:217-222 
16. Botton J, Philippat C, Calafat AM, Carles S, Charles MA, Slama R, Eden Mother-Child Cohort Study Group (2016 Nov) Phthalate pregnancy exposure and male offspring growth from the intra-uterine period to five years of age. Environmental research 151(1):601-609

17. Buha A, Antonijevic B, Bulat Z, Jacevic, V;Milovanovi'c, V, Matovi'c V (2013) The impact of prolonged cadmium exposure and co-exposure with polychlorinated biphenyls on thyroid function in rats. Toxicol Lett 221:83-90

18. Buha A, Matovic' V, Antonijevic B, Bulat Z, C` urc'ic' M, Renieri EA, Tsatsakis AM, Schweitzer A;Wallace, D. Overview of Cadmium Thyroid Disrupting Effects and Mechanisms. Int. J. Mol. Sci. $2018,19,1501$

19. Dar KK, Ali S, Ejaz M, Nasreen S, Ashraf N, Gillani SF, Shafi N, Safeer S, Khan MA4, Andleeb S, Mughal TA (2019) In vivo induction of hepatocellular carcinoma by diethylnitrosoamine and pharmacological intervention in balb c mice using Bergeniaciliata extracts. Braz J Biol 79(4):629638

20. Djordjevic AB, Antonijevic E, Curcic M, Milovanovic V, Antonijevic B (2019) Endocrine disrupting mechanisms of polychlorinated biphenyls. Curr Opin Toxicol 19:42-49

21. Docea AO, Gofita E, Goumenou M, Calina D, Rogoveanu O, Varut M, Olaru C, Kerasioti E, Fountoucidou P, Taitzoglou I et al (2018) Six months exposure to a real life mixture of 13 chemicals' below individual NOAELs induced non monotonic sex-dependent biochemical and redox status changes in rats. Food Chem Toxicol 115:470-481

22. Docea AO, Goumenou M, Calina D, Arsene AL, Dragoi CM, Gofita E, Pisoschi CG, Zlatian O, Stivaktakis PD, Nikolouzakis TK et al (2019) Adverse and hormetic effects in rats exposed for 12 months to low dose mixture of 13 chemicals: RLRS part III. Toxicol Lett 310:70-91

23. Ferreira IC, Aires E, Barreira JC, Estevinho LM. Antioxidant activity of Portuguese honey samples: Different contributions of the entire honey and phenolic extract. Food Chemistry. 2009 Jun 15;114(4):1438-43

24. Gani KM, Kazmi AA (2020) Ecotoxicological risk evaluation and regulatory compliance of endocrine disruptor phthalates in a sustainable wastewater treatment scheme. Environ Sci Pollut Res 27(8):7785-7794

25. Gopalakrishnan K, Aushev VN, Manservisi F, Falcioni L, Panzacchi S, Belpoggi F, Parada H, Garbowski G, Hibshoosh H, Santella RM, Gammon MD (2020) Gene expression profiles for low-dose exposure to diethyl phthalate in rodents and humans: a translational study with implications for breast carcinogenesis. Scientific Reports, 10(1), pp.1-12

26. Gore AC, Chappell VA, Fenton SE, Flaws JA, Nadal A, Prins GS, Toppari J, Zoeller RT (2015) EDC-2: The Endocrine Society's Second Scientific Statement on Endocrine-Disrupting Chemicals. Endocr Rev $36: 1-150$

27. Ha M, Guan X, Wei L, Li P, Yang M, Liu C (2016) Di-(2-ethylhexyl) phthalate inhibits testosterone level through disturbed hypothalamic-pituitary-testis axis and ERK-mediated 5a-Reductase 2. Science of the Total Environment. Sep 1;563:566 - 75

Page $13 / 25$ 
28. Haron MN, Mohamed M (2016) Effect of honey on the reproductive system of male rat offspring exposed to prenatal restraint stress. Andrologia 48(5):525-531

29. Harris CA, Henttu P, Parker MG, Sumpter JP (1997 Aug) The estrogenic activity of phthalate esters in vitro. Environmental health perspectives 105(8):802-811

30. Hauser R, Meeker JD, Singh NP, Silva MJ, Ryan L, Duty S, Calafat AM (2007) DNA damage in human sperm is related to urinary levels of phthalate monoester and oxidative metabolites. Hum Reprod 22(3):688-695

31. Hernandez AF, Buha A, Constantin C, Wallace DR, Sarigiannis D, Neagu M, Antonijevic B, Hayes AW, Wilks MF, Tsatsakis A (2019) Critical assessment and integration of separate lines of evidence for risk assessment of chemical mixtures. Arch Toxicol 93:2741-2757

32. Hurst $\mathrm{CH}$, Waxman DJ. Activation of PPARa and PPARy by environmental phthalate monoesters. Toxicological Sciences. 2003 Aug 1;74(2):297-308

33. Hussain S, Ali S, Mumtaz S, Shakir HA, Ahmad F, Tahir HM, Ulhaq M (2020) Dose and durationdependent toxicological evaluation of lead acetate in chicks. Environ Sci Pollut Res 27(13):1514915164

34. Ibrahim A, Mabrouk A. Abd Eldaim, and Mohamed M. Abdel-Daim. (2016). Nephroprotective effect of bee honey and royal jelly against subchronic cisplatin toxicity in rats. Cytotechnology. 2016 Aug; 68(4): 1039-1048. doi: 10.1007/s10616-015-9860-2

35. Weaver JA, Brandiese EJ, Beverly N, Keshava A, Mudipalli X, Arzuaga C, Cai AK, Hotchkiss SL, Makris EE, Yost (2020) Hazards of diethyl phthalate (DEP) exposure: A systematic review of animal toxicology studies. Environ Int 145:105848

36. Jeong HJ, Shin YG, Kim IH, Pezzuto JM. Inhibition of aromatase activity by flavonoids. Archives of pharmacal research. 1999 Jun 1;22(3):309

37. Jeong SH, Jang JH, Cho HY, Lee YB (2020) Risk assessment for humans using physiologically based pharmacokinetic model of diethyl phthalate and its major metabolite, monoethyl phthalate. Archives of Toxicology, pp.1-24

38. Kaabi AM, Barakat IAH, Alajmi RA et al (2020) Use of black seed (Nigella sativa) honey bee to improve sheep oocyte maturation medium. Environ Sci Pollut Res 27:33872-33881. https://doi.org/10.1007/s11356-020-09504-7

39. Kadiri $\mathrm{H}$ (2018) The ameliorating effects of honey on some biochemical parameters on rats exposed to cyanide. Biokemistri, 30(1)

40. Katalinica V, Modun D, Music I, Boban M (2005) Gender differences in antioxidant capacity of rat tissues determined by 2, 2'-azinobis (3-ethylbenzothiazoline 6-sulfonate; ABTS) and ferric reducing antioxidant power (FRAP) assays. Comp Biochem Physiol C: Toxicol Pharmacol 140(1):47-52

41. Khan R, Ali S, Mumtaz M, Andleeb S, Ulhaq M, Tahir HM, Khan MKA, Khan MA, Shakir HA.Toxicological effects of heavy metals (cadmium and mercury) on blood and thyroid gland and pharmacological intervention by vitamin c in rabbits. Environ Sci Pollut Res, 26(16):16727-16741 
42. Kirkman-Brown J, Björndahl L (2009) Evaluation of a disposable plastic Neubauer counting chamber for semen analysis. Fertility sterility 91(2):627-631

43. Kolawole TA, Oyeyemi WA, Adigwe C, Leko B, Udeh C, Dapper DV (2015) Honey attenuates the detrimental effects of nicotine on testicular functions in nicotine treated wistar rats. Nigerian Journal of Physiological Sciences 30(1-2):10-16

44. Lazic SE, Semenova E, Williams D (2019 Jan) Determining organ weight toxicity with Bayesian causal models: Improving on the analysis of relative organ weights. BioRxiv 1:754853

45. Li K, Liszka M, Zhou C, Brehm E, Flaws JA, Nowak RA (2020) Prenatal exposure to a phthalate mixture leads to multigenerational and transgenerational effects on uterine morphology and function in mice. Reproductive Toxicology

46. Li X, Wan J, Wang Y, Yan Z, Chi H, Ding S (2020) Mechanism of accurate recognition and catalysis of diethyl phthalate (DEP) in wastewater by novel MIL100 molecularly imprinted materials. Applied Catalysis B: Environmental, p.118591

47. Hossen MdS, Ali MdY, Jahurul MHA, Abdel-Daim MM, Gan SH, Md. Ibrahim Khalil, (2017). Beneficial roles of honey polyphenols against some human degenerative diseases: A review,Pharmacological Reports.Volume 69, Issue 6, Pages 1194-1205

48. Mohamed M, Sulaiman SA, Jaafar H, Sirajudeen KN (2011 Sep) Antioxidant protective effect of honey in cigarette smoke-induced testicular damage in rats. Int J Mol Sci 12(9):5508-5521

49. Mondal S, Ghosh S, Bhattacharya S, Mukherjee S (2019) Chronic dietary administration of lower levels of diethyl phthalate induces murine testicular germ cell inflammation and sperm pathologies: Involvement of oxidative stress. Chemosphere 229:443-451

50. Montoto LG, Arregui L, Sánchez NM, Gomendio M, Roldan ER (2012) Postnatal testicular development in mouse species with different levels of sperm competition. Reproduction, 143(3), p.333

51. Mosavat M, Mohamed M, Ooi FK, Mirsanjari M, Zin AAM, Romli AC (2019) Histological changes of female reproductive organs subjected to different jumping exercise intensities and honey supplementation in rats. PeerJ 7:.e7646

52. Moskaug J, Carlsen H, Myhrstad MC, Blomhoff R. Polyphenols and glutathione synthesis regulation. The American journal of clinical nutrition. 2005 Jan 1;81(1):277S-83S

53. Mughal TA, Saleem MZ, Ali S, Anwar KK, Bashir MM, Babar M, Khan MA (2019) Evaluation of hepatotoxicity of carbon tetrachloride and pharmacological intervention by vitamin $E$ in balb c mice. Pakistan Journal of Zoology 51(2):755-761

54. Mumtaz S, Ali S, Khan R, Andleeb S, Ulhaq M, Khan MA, Shakir HA (2019) The protective role of ascorbic acid in the hepatotoxicity of cadmium and mercury in rabbits. Environ SciPollut Res Int 26(14):14087-14096

55. Murosak S, Muroyama K, Yamamoto Y, Liu T, Yoshikai Y (2002) Nigerooligosaccharides augments natural killer activity of hepatic mononuclear cells in mice. Int Immunopharmacol 2:151-159 
56. Nasrolahi O, Khaneshi F, Rahmani F, Razi M (2013 Dec) Honey and metformin ameliorated diabetesinduced damages in testes of rat; correlation with hormonal changes. Iranian journal of reproductive medicine 11(12):1013

57. National Research Council (2009) Phthalates and cumulative risk assessment: the tasks ahead. National Academies Press

58. Nemoseck TM, Carmody EG, Furchner-Evanson A, Gleason M, Li A, Potter H, Rezende LM, Lane KJ, Kern M (2011) Honey promotes lower weight gain, adiposity, and triglycerides than sucrose in rats. Nutrition research. Jan 1;31(1):55-60

59. Oishi S, Hiraga K. Testicular atrophy induced by phthalic acid esters: effect on testosterone and zinc concentrations. Toxicology and applied pharmacology. 1980 Mar 30;53(1):35-41

60. Ozcan-Sezer S, Ince E, Akdemir A, Ceylan ÖÖ, Suzen S, Gurer-Orhan H. Aromatase inhibition by 2methyl indole hydrazone derivatives evaluated via molecular docking and in vitro activity studies. Xenobiotica. 2019 May 4;49(5):549-56

61. Pipicelli G, Tatti P (2009) Therapeutic properties of honey. Health 1(2):281-283

62. Radke EG, Braun JM, Nachman RM, Cooper GS (2020) Phthalate exposure and neurodevelopment: A systematic review and meta-analysis of human epidemiological evidence. Environment International, 137, p.105408

63. Rahman M, Brazel CS (2004) The plasticizer market: an assessment of traditional plasticizers and research trends to meet new challenges. Prog Polym Sci 29(12):1223-1248

64. Rodríguez-Carmona Y, Cantoral A, Trejo-Valdivia B et al (2019) Phthalate exposure during pregnancy and long-term weight gain in women. Environ Res 169:26-32

65. Sedha S, Lee H, Singh S, Kumar S, Jain S, Ahmad A, Bin YA, Jardan S, Sonwal, Shruti Shukla, Jesus Simal-Gandara, Jianbo Xiao, Yun Suk Huh, Young-Kyu Han, Vivek K. Bajpai., 2021. Reproductive toxic potential of phthalate compounds - State of art review. Pharmacological Research, 167:105536

66. Selvaraju K, Vikram P, Soon JM, Krishnan KT, Mohammed A (2019) Melissopalynological, physicochemical and antioxidant properties of honey from West Coast of Malaysia. J Food Sci Technol 56(5):2508-2521

67. Shaha CM, Pandit RS (2020) Biochemical and molecular changes mediated by plasticizer diethyl phthalate in Chironomus circumdatus (bloodworms). Comparative Biochemistry and Physiology Part C: Toxicology \& Pharmacology, 228, p. 108650

68. Mustafa S, Wei Q 1, Wael Ennab 1, Zengpeng Lv 1, Korejo Nazar 2, Farman Ali Siyal 2, Saif Rodeni 1 , Ngekure M. X. Kavita 1 and Fangxiong Shi. Resveratrol Ameliorates Testicular Histopathology of Mice Exposed to Restraint Stress. 2019, Animals 9, 743

69. Spalding KL, Arner E, Westermark PO, Bernard S, Buchholz BA, Bergmann O, Blomqvist L, Hoffstedt J, Näslund E, Britton T, Concha H. Dynamics of fat cell turnover in humans. Nature. 2008 Jun;453(7196):783 
70. Sultan Ayoub Meo, ${ }^{\mathrm{a},}$ Saleh Ahmad Al-Asiri, ${ }^{\mathrm{b}}$ Abdul Latief Mahesar, ${ }^{\mathrm{c}}$ and Mohammad Javed Ansari ${ }^{\mathrm{d}}$ Role of honey in modern medicine. Saudi J Biol Sci. 2017 Jul; 24(5): 975-978

71. Tanner EM, Hallerbäck MU, Wikström S, Lindh C, Kiviranta H, Gennings C, Bornehag CG (2020) Early prenatal exposure to suspected endocrine disruptor mixtures is associated with lower IQ at age seven. Environment international, 134, p.105185

72. Terzo S, Mulè F, Amato A. Honey and obesity-related dysfunctions: a summary on health benefits. The Journal of Nutritional Biochemistry. 2020, 82; 108401

73. Tsatsakis AM, Kouretas D, Tzatzarakis MN, Stivaktakis P, Tsarouhas K, Golokhvast KS, Rakitskii VN, Tutelyan VA, Hernandez AF, Rezaee R et al (2017) Simulating real-life exposures to uncover possible risks to human health: A proposed consensus for a novel methodological approach. Hum Exp Toxicol 36:554-564. [CrossRef]

74. Valverde Malaver CL, Colmenares Dulcey AJ, Isaza Martínez JH (2015) Comparison of DPPH free radical scavenging, ferric reducing antioxidant power (FRAP), and total phenolic content of two meriania species (Melastomataceae). Revista de Ciencias 19(2):117-124

75. Vandenberg LN, Ma_ni MV, Sonnenschein C, Rubin BS, Soto AM (2009) Bisphenol-a and the great divide:A review of controversies in the field of endocrine disruption. Endocr Rev 30:75-95.]

76. Vela L, de Lorenzo C, Perez RA. Antioxidant capacity of Spanish honeys and its correlation with polyphenol content and other physicochemical properties. Journal of the Science of Food and Agriculture. 2007 Apr 30;87(6):1069-75

77. Zheng SJ, Tian HJ, Cao J, Gao YQ (2010) Exposure to di (n-butyl) phthalate and benzo (a) pyrene alters IL-1 $\beta$ secretion and subset expression of testicular macrophages, resulting in decreased testosterone production in rats. Toxicology and applied pharmacology. Oct 1;248(1):28-37

78. Zhou Y, Huang M, Wang X, Gao J, Fang G, Zhou D (2020) Efficient transformation of diethyl phthalate using calcium peroxide activated by pyrite. Chemosphere, p.126662

\section{Tables}

Table 1. Bodyweight gain gonado-somatic index and seminiferous tubules micrometry of DEP exposed mice with and without honey against control. 


\begin{tabular}{|c|c|c|c|c|c|c|}
\hline $\begin{array}{l}\text { Dose Groups / } \\
\text { Parameters }\end{array}$ & $\begin{array}{c}\mathrm{C} \\
(\mathrm{N}=10)\end{array}$ & $\begin{array}{c}\mathrm{VC} \\
(\mathrm{N}=10)\end{array}$ & $\begin{array}{l}\text { DEP } \\
(N=10)\end{array}$ & $\begin{array}{l}\mathrm{HC} \\
(\mathrm{N}=10)\end{array}$ & $\begin{array}{l}\mathrm{P}+\mathrm{H} \\
(\mathrm{N}=10)\end{array}$ & $\begin{array}{c}\mathrm{P} \\
\text { Value }\end{array}$ \\
\hline $\begin{array}{l}\text { Initial body weight of } \\
\text { mice(gm) }\end{array}$ & $13.84 \mathrm{a} \pm 0.22$ & $13.50 \mathrm{a} \pm 0.33$ & $13.54 \mathrm{a} \pm 0.27$ & $13.72 \mathrm{a} \pm 0.27$ & $13.78 a \pm 0.26$ & 0.875 \\
\hline $\begin{array}{l}\text { Final body weight of mice } \\
\text { (gm) }\end{array}$ & $30.80 \mathrm{~b} \pm 0.34$ & $30.58 \mathrm{~b} \pm 0.44$ & $33.29 \mathrm{a} \pm 0.30$ & $28.34 c \pm 0.73$ & $30.57 \mathrm{~b} \pm 0.43$ & 0.000 \\
\hline Test weight (mg) & $124.1^{\mathrm{b}} \pm 1.58$ & $128.2^{\mathrm{b}} \pm 0.8$ & $110.0^{\mathrm{a}} \pm 2.1$ & $123.8^{\mathrm{b}} \pm 0.8$ & $128.7^{\mathrm{b}} \pm 0.6$ & 0.000 \\
\hline $\begin{array}{l}\text { Gonado somatic index } \\
\text { (GSI) }\end{array}$ & $0.40 \mathrm{~b} \pm 0.008$ & $0.42 \mathrm{~b} \pm 0.007$ & $0.33 a \pm 0.006$ & $0.43 \mathrm{~b} \pm 0.001$ & $0.42 \mathrm{~b} \pm 0.007$ & 0.000 \\
\hline $\begin{array}{l}\text { Mean Seminiferous } \\
\text { tubular diameter }(\mu \mathrm{m})\end{array}$ & $243.3 b \pm 0.77$ & $\begin{array}{l}218.9 \mathrm{~d} \pm \\
0.69\end{array}$ & $\begin{array}{l}204.8 \mathrm{e} \pm \\
0.92\end{array}$ & $\begin{array}{l}253.1 \mathrm{a} \pm \\
0.52\end{array}$ & $225.9 c \pm 0.68$ & 0.000 \\
\hline $\begin{array}{l}\text { Mean Luminal } \\
\text { Diameter }(\mu \mathrm{m})\end{array}$ & $67.1 \mathrm{c} \pm 0.3$ & $77.3 \mathrm{~b} \pm 0.7$ & $92.0 \mathrm{a} \pm 0.5$ & $63.0 \mathrm{~d} \pm 0.7$ & $65.0 \mathrm{~cd} \pm 0.7$ & 0.000 \\
\hline $\begin{array}{l}\text { Seminiferous tubule area } \\
\left(\mathrm{mm}^{2}\right)\end{array}$ & $0.046 a \pm 0.41$ & $0.037 \mathrm{~b} \pm 0.07$ & $\begin{array}{c}0.033 \mathrm{c} \pm \\
0.009\end{array}$ & $\begin{array}{c}0.050 \mathrm{a} \pm \\
0.06\end{array}$ & $0.041 \mathrm{~b} \pm 0.059$ & 0.000 \\
\hline Luminal Area $\left(\mathrm{mm}^{2}\right)$ & $\begin{array}{l}0.0035 \mathrm{~b} \pm \\
0.002\end{array}$ & $\begin{array}{l}0.0047 \mathrm{c} \pm \\
0.004\end{array}$ & $\begin{array}{l}0.0066 \mathrm{a} \pm \\
0.0001\end{array}$ & $\begin{array}{l}0.0031 \mathrm{~b} \pm \\
0.0002\end{array}$ & $\begin{array}{l}0.0034 \mathrm{~b} \pm \\
0.0002\end{array}$ & 0.000 \\
\hline Epithelial Area $\left(\mathrm{mm}^{2}\right)$ & $0.0425^{\mathrm{b}} \pm 0.001$ & $\begin{array}{c}0.0323^{C} \pm \\
0.038\end{array}$ & $\begin{array}{l}0.0264^{\mathrm{a}_{ \pm}} \\
0.001\end{array}$ & $\begin{array}{c}0.0469 \mathrm{~b} \\
0.006\end{array}$ & $\begin{array}{r}0.0367^{\mathrm{C}} \pm \\
0.007\end{array}$ & 0.000 \\
\hline
\end{tabular}

Note: Values are expressed as mean \pm SEM; $\mathbf{N}=$ Number of samples analyzed; C, untreated; VC, corn oil treated DEP, diethyl phthalate exposed; $\mathbf{P}+\mathbf{H}$, diethyl phthalate + honey; HC, honey, In rows different alphabets showed significant difference among groups analyzed through one-way ANOVA followed Tukey's post hoc at level minimally P $\leq 0.05$.

Table 2. Comparison of Hormonal variations, sperm count, percentages of normal to abnormal sperms among DEP treated groups with and without honey against controls.

\begin{tabular}{|c|c|c|c|c|c|c|}
\hline Dose Groups / & $\begin{array}{c}\mathrm{C} \\
(\mathrm{N}=10)\end{array}$ & $\begin{array}{c}\mathrm{VC} \\
(\mathrm{N}=10)\end{array}$ & $\begin{array}{c}\text { DEP } \\
(\mathrm{N}=10)\end{array}$ & $\begin{array}{c}\mathrm{HC} \\
(\mathrm{N}=10)\end{array}$ & $\begin{array}{c}\mathrm{P}+\mathrm{H} \\
(\mathrm{N}=10)\end{array}$ & $\begin{array}{c}\mathrm{P} \\
\text { Value }\end{array}$ \\
\hline Parameters & & & & & & \\
\hline Testosterone level (ng/ml) & $\begin{array}{l}0.24 \mathrm{~b} \pm \\
0.22\end{array}$ & $0.22 \mathrm{~b} \pm 0.02$ & $\begin{array}{l}0.10 \mathrm{c} \pm \\
0.005\end{array}$ & $\begin{array}{l}0.48 \mathrm{a} \pm \\
0.16\end{array}$ & $\begin{array}{l}0.23 \mathrm{~b} \pm \\
0.26\end{array}$ & 0.000 \\
\hline $\begin{array}{l}\text { Luteinizing hormone } \\
\text { (mlU/ml) }\end{array}$ & $1.66 \mathrm{~b} \pm 0.38$ & $1.56 \mathrm{~b} \pm 0.08$ & $\begin{array}{l}2.02 \mathrm{a} \pm \\
0.53\end{array}$ & $\begin{array}{l}0.49 \mathrm{c} \pm \\
0.09\end{array}$ & $\begin{array}{c}1.57 \mathrm{~b} \pm \\
0.036\end{array}$ & 0.000 \\
\hline Sperm count (million/ml) & $41.8 \mathrm{~b} \pm 1.1$ & $41.8 \mathrm{~b} \pm 1.0$ & $24.7 \mathrm{c} \pm 0.5$ & $49.4 \mathrm{a} \pm 2.2$ & $40.9 \mathrm{~b} \pm 1.3$ & 0.000 \\
\hline Normal sperms (\%) & $67.5 \mathrm{~b} \pm 1.2$ & $69.3 \mathrm{~b} \pm 1.2$ & $59.6 \mathrm{a} \pm 0.8$ & $79.2 \mathrm{c} \pm 1.2$ & $70.0 \mathrm{~b} \pm 1.6$ & 0.000 \\
\hline Abnormal sperms (\%) & $32.5 b \pm 1.2$ & $30.7 b \pm 1.2$ & $40.4 \mathrm{a} \pm 0.8$ & $20.8 \mathrm{c} \pm 1.2$ & $30.0 \mathrm{~b} \pm 1.6$ & 0.000 \\
\hline $\begin{array}{l}\text { FRAP value } \\
\text { ( } \mathrm{MM} \text { ascorbic acid equi/ mg) }\end{array}$ & $\begin{array}{c}247.65 \mathrm{C} \pm \\
0.0005\end{array}$ & $\begin{array}{l}250.67 \mathrm{~b} \pm \\
0.0005\end{array}$ & $\begin{array}{l}112.54 \mathrm{e} \pm \\
0.0005\end{array}$ & $\begin{array}{l}282.9 \mathrm{a} \pm \\
0.0005\end{array}$ & $\begin{array}{l}241.6 \mathrm{~d} \pm \\
0.0005\end{array}$ & 0.000 \\
\hline
\end{tabular}

Note: Values are expressed as mean $\mathbf{S E M} ; \mathbf{N}=$ Number of samples analyzed; $\mathbf{C}$, untreated; VC, corn oil treated DEP, diethyl phthalate exposed; $\mathbf{P}+\mathbf{H}$, diethyl phthalate + honey; HC, honey treated; FRAP, ferric reducing antioxidant power in testes homogenates. In rows different alphabets showed significant difference among groups analyzed through one-way ANOVA followed Tukey's post hoc at level minimally P $\leq 0.05$. 
Table 3- Histopathological lesions scoring in testes of mice in different treatment categories.

\begin{tabular}{|c|c|c|c|c|c|c|c|}
\hline Groups & $\mathrm{C}$ & VC & $\overline{\mathrm{DEP}}$ & $\mathrm{P}+\mathrm{H}$ & $\mathrm{HC}$ & Chi & $\begin{array}{l}\mathrm{P} \\
\text { value }\end{array}$ \\
\hline $\begin{array}{l}\text { (Total sections examined) } \\
\text { Testis lesions }\end{array}$ & (10) & (10) & (10) & (10) & (10) & & \\
\hline Vacoulations & $\begin{array}{c}0 \\
(0 \%)\end{array}$ & $\nabla_{4}(40 \%)$ & $7(70 \%)$ & $\begin{array}{c}2 \\
(20 \%)\end{array}$ & $\begin{array}{c}1 \\
(10 \%)\end{array}$ & 14.099 & .004 \\
\hline Exfoliations & $\begin{array}{c}1 \\
(10 \%)\end{array}$ & $1(10 \%)$ & $6(60 \%)$ & $\begin{array}{c}3 \\
(30 \%)\end{array}$ & $\begin{array}{c}0 \\
(0 \%)\end{array}$ & 11.306 & .012 \\
\hline Lydig cells hypoplasia & $\begin{array}{c}0 \\
(0 \%)\end{array}$ & $1(10 \%)$ & $9(90 \%)$ & $\begin{array}{c}2 \\
(20 \%)\end{array}$ & $\begin{array}{c}0 \\
(0 \%)\end{array}$ & 26.075 & .000 \\
\hline Degenerative germ cells & $\begin{array}{c}0 \\
(0 \%)\end{array}$ & $0(0 \%)$ & $10(100 \%)$ & $\begin{array}{c}4 \\
(40 \%)\end{array}$ & $\begin{array}{c}0 \\
(0 \%)\end{array}$ & 35.893 & .000 \\
\hline $\begin{array}{l}\text { Degeneration of } \\
\text { seminiferous tubules }\end{array}$ & $\begin{array}{c}0 \\
(0 \%)\end{array}$ & $0(0 \%)$ & $6(60 \%)$ & $\begin{array}{c}0 \\
(0 \%)\end{array}$ & $\begin{array}{c}0 \\
(0 \%)\end{array}$ & 16.508 & .000 \\
\hline $\begin{array}{l}\text { Sloughing of } \\
\text { spermatogenic cells }\end{array}$ & $\begin{array}{c}0 \\
(0 \%)\end{array}$ & $1(10 \%)$ & $8(80 \%)$ & $\begin{array}{c}2 \\
(20 \%)\end{array}$ & $\begin{array}{c}0 \\
(0 \%)\end{array}$ & 20.954 & .000 \\
\hline Pyknotic Nuclei & $\begin{array}{c}0 \\
(0 \%)\end{array}$ & $2(20 \%)$ & $6(60 \%)$ & $\begin{array}{c}1 \\
(10 \%)\end{array}$ & $\begin{array}{c}0 \\
(0 \%)\end{array}$ & 13.071 & .003 \\
\hline Amyloid & $\begin{array}{c}0 \\
(0 \%)\end{array}$ & $0(0 \%)$ & $4(40 \%)$ & $\begin{array}{c}0 \\
(0 \%)\end{array}$ & $\begin{array}{c}0 \\
(0 \%)\end{array}$ & 9.484 & .005 \\
\hline Dystrophic Mineralization & $\begin{array}{c}0 \\
(0 \%) \\
\end{array}$ & $0(0 \%)$ & $9(90 \%)$ & $\begin{array}{c}0 \\
(0 \%) \\
\end{array}$ & $\begin{array}{c}0 \\
(0 \%) \\
\end{array}$ & 31.379 & .000 \\
\hline Sperm retention & $\begin{array}{c}0 \\
(0 \%)\end{array}$ & $0(0 \%)$ & $0(0 \%)$ & $\begin{array}{c}4 \\
(40 \%)\end{array}$ & $\begin{array}{c}0 \\
(0 \%)\end{array}$ & 9.484 & .005 \\
\hline
\end{tabular}

Note: Sign $\nabla$ indicates number of sections in which this particular defect seen

\section{Figures}



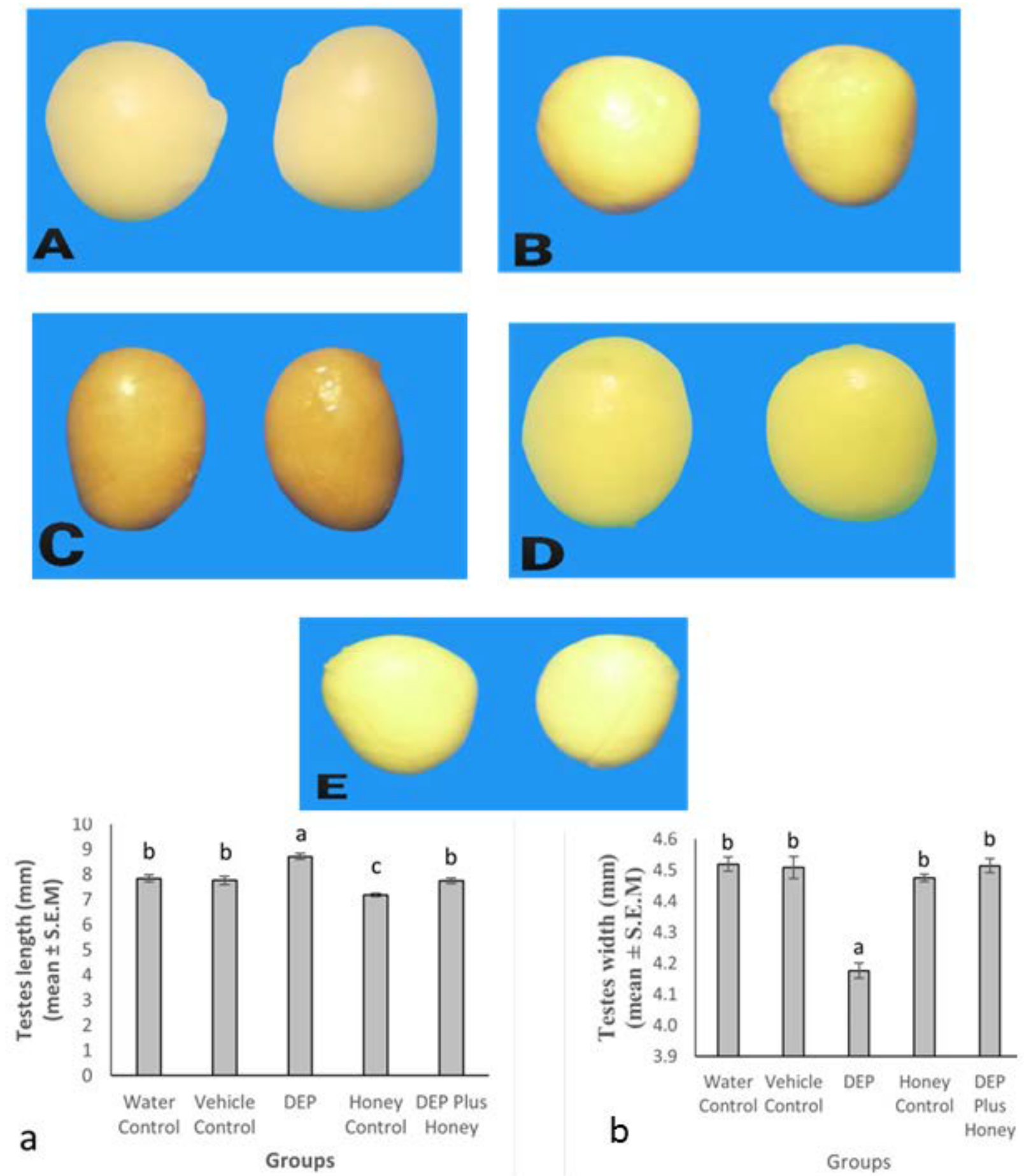

\section{Figure 1}

Macro photographs of testes and Bar graphs of morphometric measurements of Paired testes represented as). A: Control group, B: Vehicle Control, C: DEP group, D: DEP co-administered with Honey, E: Honey Control, Bar Graph showed a statistical Comparison of testes a) length and $b$ ) width. Different alphabets on bars of the same graph are statistically significant at $P \leq 0.05$. 

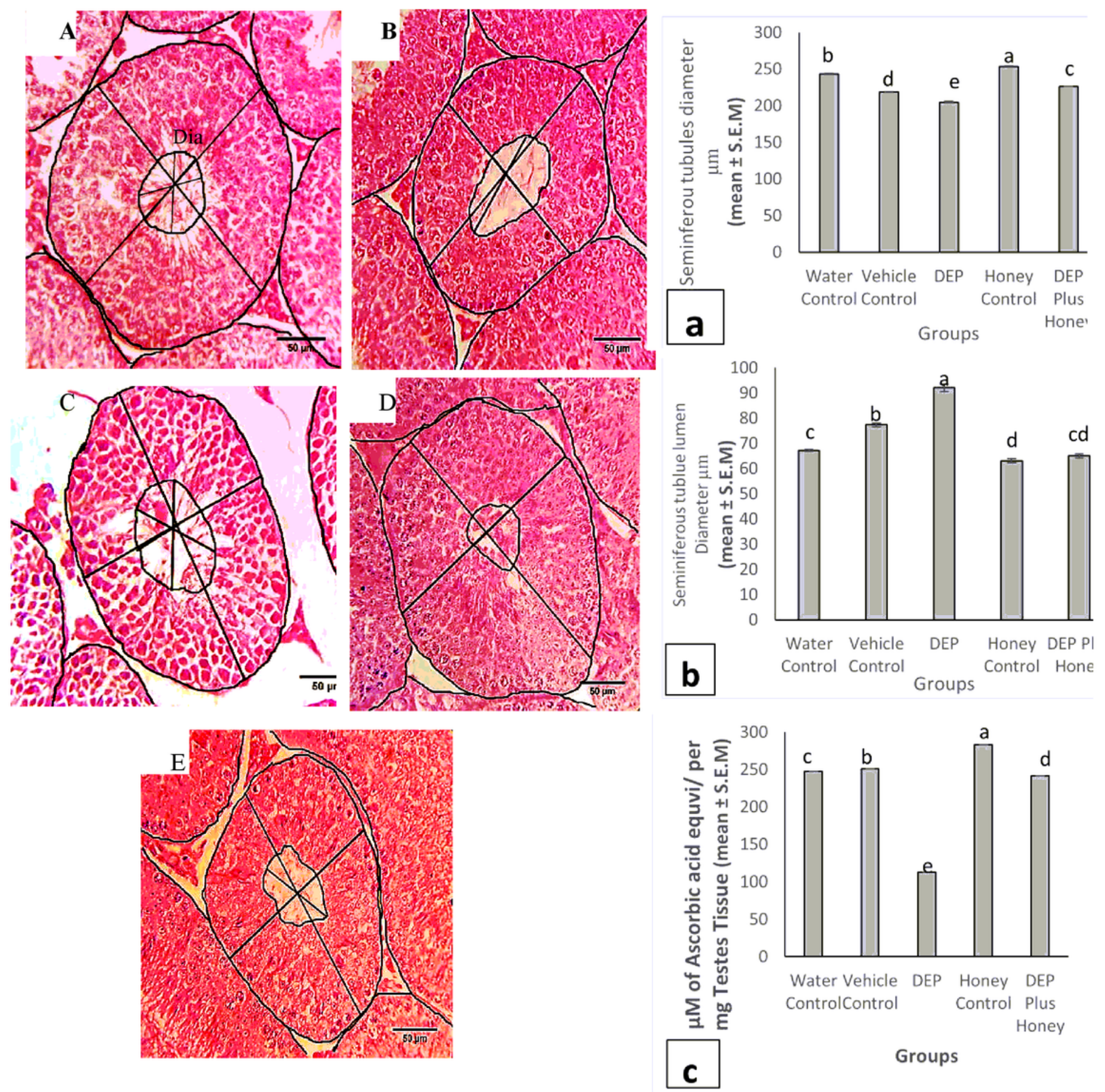

\section{Figure 2}

Photomicrographs of magnified seminiferous tubules calibrated with image $\mathrm{J}$ software. A: Control group, B: Vehicle Control, C: DEP group, D: DEP co-administered with Honey, E: Honey Control, Bar Graph showed a statistical Comparison of a) Seminiferous tubule diameter $(\mu \mathrm{m}) \mathrm{b}$ ) seminiferous lumen diameter $(\mu \mathrm{m})$ between five groups received different treatments. Bar Graph showed a statistical c) comparison for Antioxidant capacity $(\mu \mathrm{M} / \mathrm{mg})$ in Testes Tissue between five groups received different treatments expressed in mean \pm S.E.M followed by Tukey's Post Hoc Test. (H \& E stain; magnification 40X; scale bar 
$50 \mu \mathrm{m})$. Different alphabets on bars of the same graph are showing significant differences among groups minimally $P \leq 0.05$.
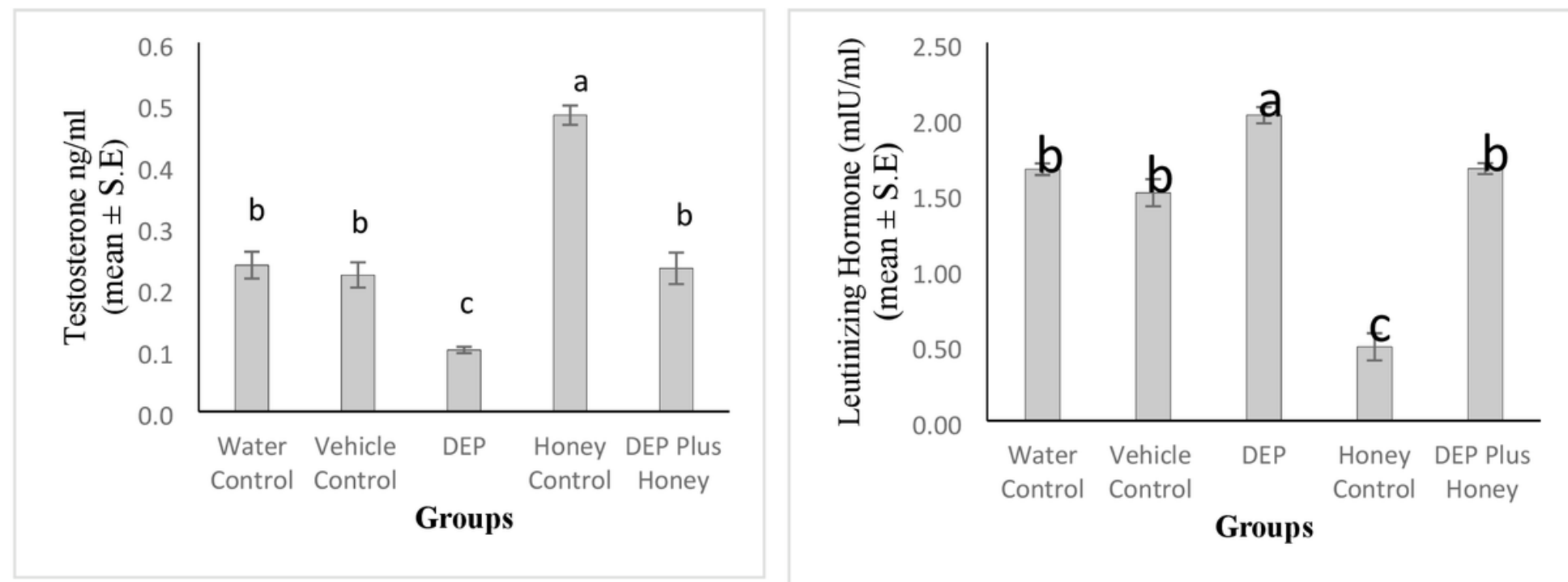

\section{Figure 3}

Bar Graph showed a statistical Comparison of Luteinizing Hormone and Testosterone Level in Plasma $(\mathrm{mlU} / \mathrm{ml})$ between five groups received different treatments expressed in mean \pm S.E followed by Tukey's Post Hoc Test. 
Total Antioxidant Capacity of Honey checked by TPC and FRAP Assay.

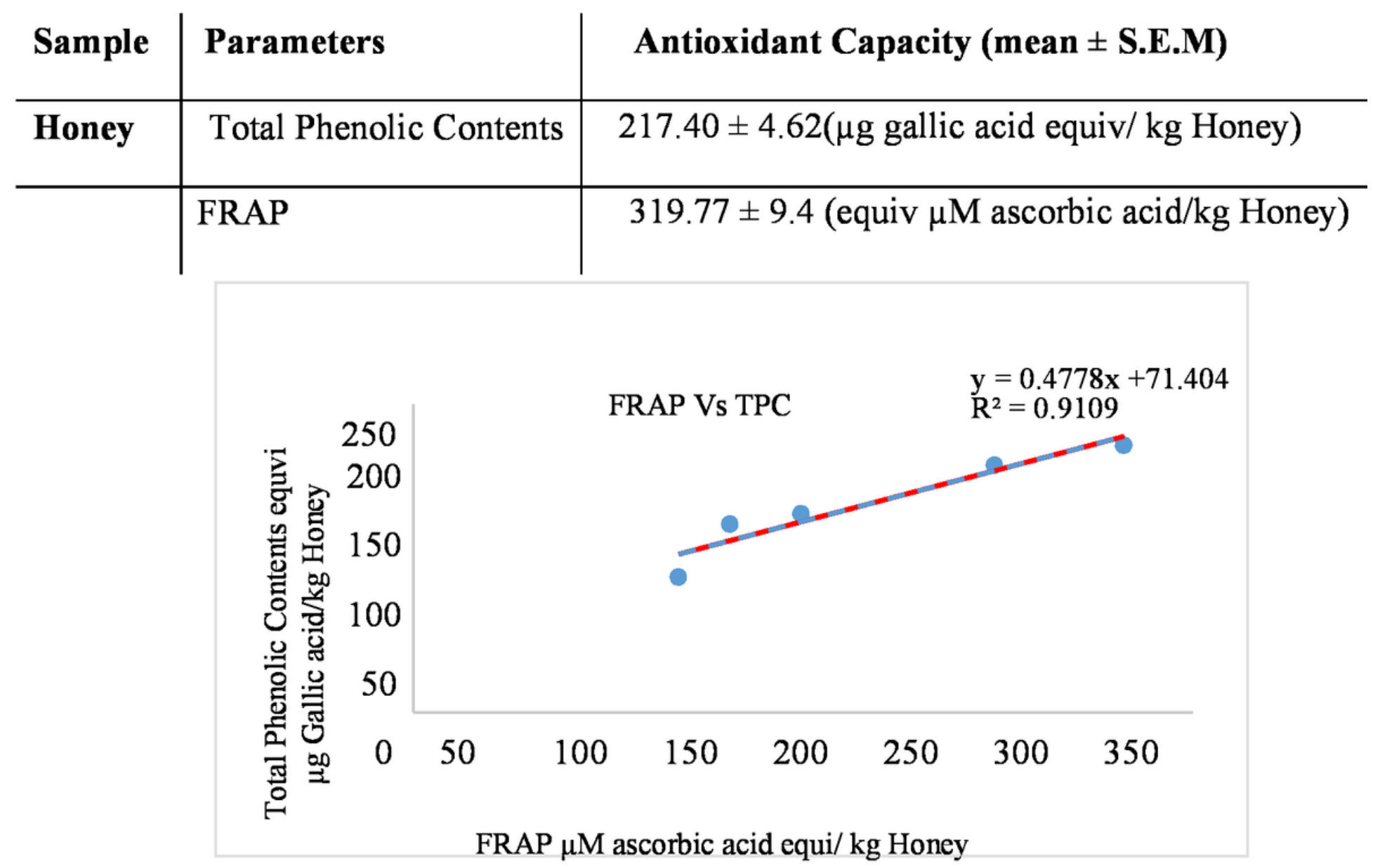

Figure 4

Correlation between FRAP and Total Phenolic Contents of Honey for Total Antioxidant Capacity. 

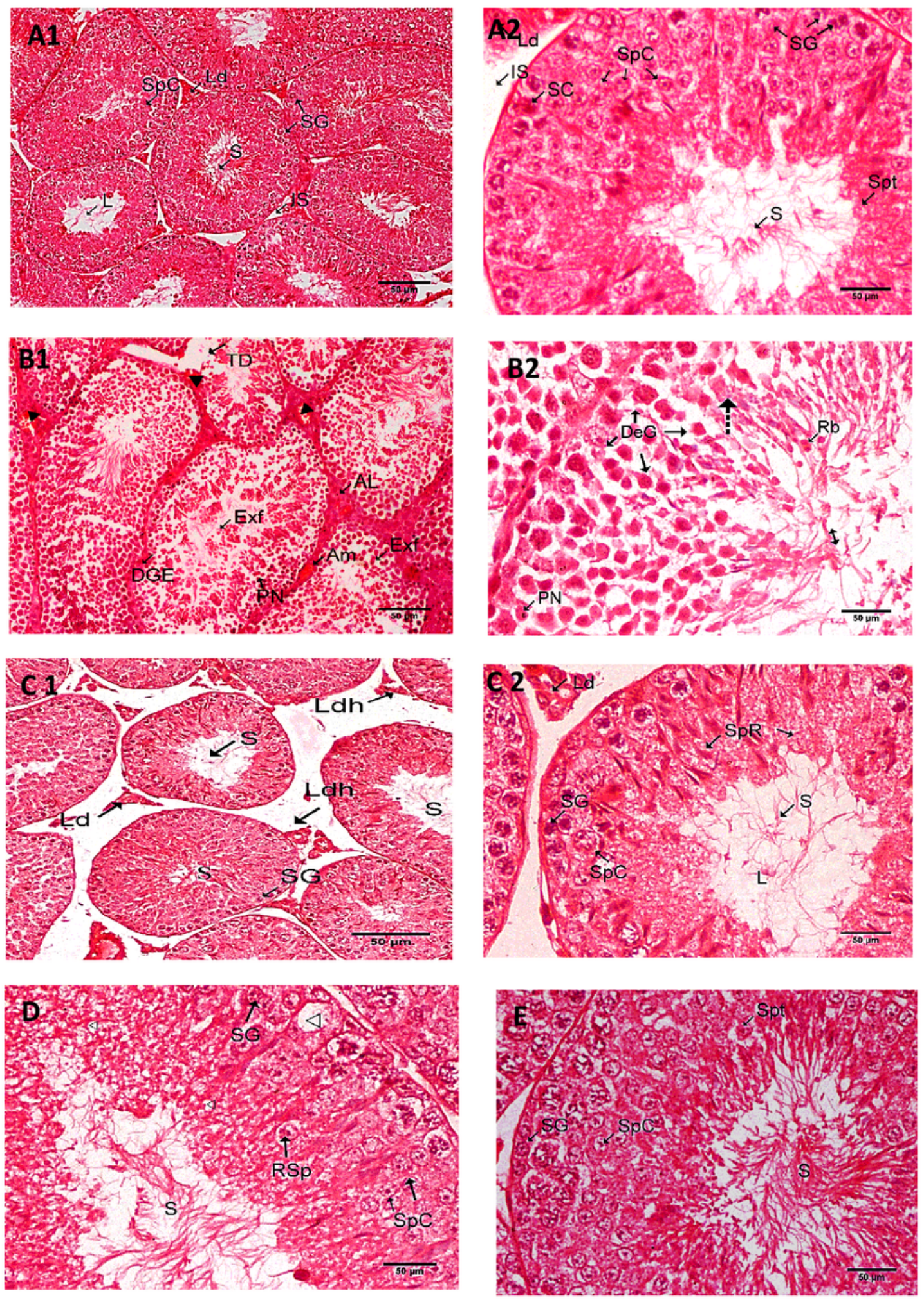

\section{Figure 5}

Photomicrographs of histological sections of testes. A1 and A2: Control group, B1 and B2: DEP group, C1 and C2: DEP co-administered with Honey, D: Vehicle Control Group E: Honey Control. Labeled as SG: spermatogonia, SpC: spermatocyte, Spt: spermatid, S: sperm, Ld: Leydig cells, L: lumen, SC: Sertoli cells, SM: smooth muscle cells, IS: Interstitials space Exf: exfoliation, RS: residual bodies, DeG: degenerative germ cells, DGE: Degenerative germinal epithelium, Am: Amyloid, solid triangle: dystrophic mineralization, 
PN: pyknotic nuclei, SpR: spermatid retention, triangle: vacuolation, double headed arrow: disrupted spermiation, Ldh: leydig cell hypoplasia (H \& E stain ;A1, B1, C1 at 10X; A2,B2,C2,D \& E at 40X; scale bar $50 \mu \mathrm{m})$. 